\title{
PENGARUH MODEL PEMBELAJARAN INQUIRY TERHADAP HASIL BELAJAR SISWA MATERI OPERASI HITUNG BILANGAN CACAH DI KELAS VI SEKOLAH DASAR
}

\author{
Moch Nurhadi ${ }^{1 *}$, Sri Surachmi W ${ }^{1}$, Sri Utaminingsih ${ }^{1}$ \\ ${ }^{1}$ Program Magister Pendidikan Dasar Fakultas Keguruan Dan Ilmu Pendidikan \\ Universitas Muria Kudus \\ * Email: moch.nurhadi78@gmail.com
}

\begin{abstract}
Abstrak
Salah satu upaya dalam meningkatkan hasil belajar siswa yaitu dengan menggunakan model pembelajaran yang menarik dan inovatif agar siswa mendapatkan hasil belajar yang maksimal khususnya dalam mata pelajaran Matematika. Upaya yang dapat memperbaiki suasana belajar yang menarik sehingga hasil belajar siswa meningkat dalam kegiatan pembelajaran melalui model pembelajaran yang tepat. Penelitian ini bertujuan untuk menemukan pengaruh penggunaan model pembelajaran Inquiry terhadap peningkatan hasil belajar siswa pada materi operasi hitung bilangan cacah di kelas VI Sekolah Dasar di Gugus Gajah Mada Kecamatan Dempet Kabupaten Demak. Penelitian yang digunakan adalah penelitian eksperimen dengan pendekatan kuantitatif. Rancangan design penelitian ini menggunakan quasi experiment dengan bentuk nonequivalent control group design dan tehnik penelitian melalui tes pilihan ganda pre test dan post test. Dimana SD Negeri Balerejo I menggunakan model Inqury dan SD Negeri Brakas menggunakan model Konvensional. Hasil penelitian terdapat pengaruh model pembelajaran Inquiry terhadap peningkatan hasil belajar siswa pada materi operasi hitung bilangan cacah di kelas VI SD Negeri Balerejo I memiliki rata-rata kelas sebesar 74,93 dan ketuntasan hasil belajar $100 \%$. Berdasarkan penelitian dapat disimpulkan bahwa model pembelajaran Inquiry dapat meningkatkan hasil belajar siswa materi Operasi Hitung Bilangan Cacah di Kelas VI Sekolah Dasar di Gugus Gajah Mada Kecamatan Dempet Kabupaten Demak oleh karena itu guru harus terus berusaha mengembangkan inovasi pembelajaran agar hasil belajar siswa terus meningkat.
\end{abstract}

Kata Kunci: Pengaruh, Inkuiri dan Hasil Belajar

\begin{abstract}
One effort to improve student learning outcomes is to use attractive and innovative learning models so that students get maximum learning outcomes, especially in Mathematics. Efforts that can improve an interesting learning atmosphere so that student learning outcomes increase in learning activities through appropriate learning models. This study aims to find the effect of the use of Inquiry learning model on the improvement of student learning outcomes in material count counting operations in class VI Elementary School in the Gajah Mada Cluster, Dempet District, Demak Regency. The research used was experimental research with a quantitative approach. The design of this research design uses quasi experiment with the form of nonequivalent control group design and research techniques through multiple choice tests pre test and post test. Where experiment class 1 of SD Negeri Balerejo I uses the Inqury model and experiment class 2 of SD Negeri Brakas uses conventional models. Results of the study There is an influence of Inquiry learning model on the improvement of student learning outcomes in count number operations in grade VI of SD Negeri Balerejo I have an average class of 74.93 and $100 \%$ completeness of learning outcomes. Based on the research it can be concluded that the Inquiry learning model can improve student learning outcomes Material Count Numbers Operations in Class VI Elementary Schools in the Gajah Mada Cluster Dempet District Demak Regency, therefore teachers must continue to try to develop learning innovations so that student learning outcomes continue to increase.
\end{abstract}

Keywords: Influence, Inquiry and Learning Outcomes 


\section{PENDAHULUAN}

\section{Latar Belakang}

Pendidikan merupakan sarana terpenting untuk mewujudkan kemajuan bangsa dan negara, hal ini karena pendidikan merupakan proses yang bertujuan untuk meningkatkan kualitas hasil belajar siswa agar meraih prestasi yang diinginkan. Penggunaan model pembelajaran yang tidak tepat dapat berdampak pada kegiatan pembelajaran yang cepat membosankan, sehingga materi yang disampaikan sulit diterima oleh peserta didik, dalam hal ini akan berdampak pada hasil belajar peserta didik rendah. Misalnya, peserta didik menjadi malas untuk berhadapan dengan mata pelajaran matemarika.

Hasil belajar tidak dapat terpisah dari proses belajar itu sendiri. Hal ini disebabkan hasil belajar muncul karena adanya aktivitas belajar. Manusia sejak lahir telah memiliki bakat bawaan untuk belajar. Belajar adalah aktivitas manusia yang vital dan secara terus menerus akan dilakukan selama manusia tersebut masih hidup (Thobroni, 2016:15). Hal ini senada dengan pendapat Pranowo, (2014: 32) yang menyatakan bahwa belajar merupakan proses terus menerus dalam arti setiap menghadapi persoalan baru akan dikonstruk kembali berdasarkan pengetahuan yang sudah dimiliki agar terbentuk pengalaman baru yang lain. Dari pernyataan tersebut dapat diketahui bahwa belajar akan membawa perubahan pada setiap individu. Perubahan yang terjadi atau terbentuk selama belajar ini yang kemudian disebut sebagai hasil belajar.

Berlandaskan pada konsep belajar di atas, maka dapat diketahui bahwa hasil belajar seseorang bergantung pada apa yang telah diketahui sebelumnya yang diwujudkan menjadi pengetahuan baru. Hasil belajar yang dimaksudkan pada pernyataan di atas ialah kemampuan yang diperoleh siswa setelah melalui kegiatan belajar (Susanto, 2013:5). Dengan kata lain, Soedijarto (dalam Purwanto, 2011: 46) menyatakan bahwa hasil belajar adalah tingkat penguasaan yang dicapai oleh peserta didik dalam mengikuti proses belajar mengajar sesuai dengan tujuan pendidikan yang telah ditetapkan.

Salah satu upaya dalam meningkatkan hasil belajar siswa, yaitu memperbaiki model atau metode pembelajaran. Model pembelajaran merupakan suatu konsep atau cara yang dibuat dalam proses belajar mengajar mengacu pada tujuan-tujuan pembelajaran, tahap-tahap dalam kegiatan pembelajaran, lingkungan pembelajaran, dan pengelolaan kelas. Permasalahan-permasalahan yang terjadi dalam kegiatan pembelajaran ialah terdapat pada penggunaan model pembelajaran yang digunakan oleh pendidik kurang efektif dan kurang menumbuhkan pembelajaran yang demokratis, sehingga dibutuhkan inovasi dalam pembelajaran dengan menerapkan model pembelajaran yang dapat menumbuhkan motivasi belajar dan peserta didik mendapatkan hasil belajar yang maksimal khususnya dalam mata pelajaran matematika. Upaya yang dapat memperbaiki suasana belajar yang efektif, sehingga lebih melibatkan peserta didik dalam kegiatan pembelajaran berlangsung yaitu melalui model pembelajaran inquiry. Tujuannya ialah agar dapat meningkatkan keterampilan peserta didik untuk bekerja sama, menumbuhkan keterampilan berpikir kritis, dan mampu memecahkan masalah-masalah dalam kehidupan sehari-hari, khususnya dalam pembelajaran matematika.

Berdasarkan permasalahan diatas di Gugus Gajah Mada kelas VI Sekolah Dasar Kecamatan Dempet Kabupaten Demak untuk mata pelajaran matematika materi Operasi Hitung Bilangan Cacah di Kelas VI Sekolah Dasar masih rendah di bawah KKM. Untuk itu diperlukan inovasi model pembelajaran yang bisa digunakan untuk menumbuhkan dan meningkatkan hasil belajar siswa yaitu dengan menggunakan model pembelajaran Inquiry.

\section{Tujuan dan Manfaat Penelitian}

Tujuan penelitian ini untuk mengetahui dan menemukan pengaruh model pembelajaran Inquiry terhadap peningkatan hasil belajar siswa pada materi operasi hitung bilangan cacah di kelas VI SD di Gugus Gajah Mada Kecamatan Dempet Kabupaten Demak.

\section{Manfaat Penelitian}

Manfaat dalam penelitian ini yaitu manfaat teoritis dan manfaat praktis sebagai berikut:

\section{Manfaat Teoritis}

Manfaat penelitian ini diharapkan dalam menambah khasanah ilmu pendidikan khususnya secara teoritis tentang peningkatan dan hasil belajar melalui metode pembelajara Inquiry, sekaligus 
penyempuranan kekurangan penelitian-penelitian terdahulu dalam penelitian yang sekarang.

2. Manfaat Prakris

a. Bagi Siswa

Model pembelajaran Inquiry mendorong siswa agar bisa memecahkan masalah atau persoalan yang dihadapi dalam kehidupan sehari-hari yang berkaitan dengan mata pelajaran matematika.

b. Bagi Guru

Penggunaan model pembelajaran Inquiry membantu guru dalam meningkatkan hasil belajar siswa di kelasnya terutama pada mata pelajaran matematika.

c. Bagi sekolah

Penerapan model pembelajaran Inquiry membantu sekolah untuk meningkatkan hasil belajar siswa khususnya untuk mata pelajaran matematika.

d. Manfaat bagi peneliti

Peneliti dapat menggunakan hasil penelitian sebagai acuan untuk menerapkan pembelajaran dengan model pembelajaran inquiry pada sekolah masing-masing.

\section{METODE PENELITIAN}

\section{Lokasi Penelitian}

Penelitian ini dilakukan pada siswa kelas VI SD di Gugus Gajah Mada Kecamatan Dempet Kabupaten Demak dengan pengambilan sampel yaitu Kelas VI SD Negeri Balerejo I dan Kelas VI SD Negeri Brakas.

\section{Metode yang digunakan}

Pendekatan yang digunakan dalam pe-

nelitian ini adalah penelitian eksperimen dengan pendekatan kuantitatif. Menurut (Sugiyono,2012:7) data penelitian pada pendekatan kuantitatif berupa angka-angka dan analisis menggunakan statistik. Rancangan desain yang digunakan dalam penelitian ini adalah Quasi Eksperimen Design dengan bentuk nonequivalent control group design. Kelas VI SD Negeri Balerejo 1 sebagai kelas ekperimen dengan model Inquiry sedangkan Kelas VI SD Negeri Brakas dengan pembelajaran konvensional.

\section{HASIL DAN PEMBAHASAN}

\section{Hasil Penelitian}

Hasil Pelaksanan Pre-test dan post-test kelas Model Pembelajaran Inquiri di SD Negeri Balerejo 1

Penelitian model pembelajaran Inquiri terhadap peningkatan hasil belajar siswa pada materi operasi hitung bilangan cacah kelas VI sekolah dasar. Pada kelas eksperimen model inquiry yaitu SD Negeri Balerejo 1 dilaksanakan pada tanggal 14, tanggal 16, tanggal 21 dan tanggal 23 bulan Januari 2020 dengan empat kali pertemuan yaitu pertemuan pertama memberikan prestest untuk mengetahui kemampuan awal siswa, kemudian pertemuan kedua dan ketiga dan pertemuan ke empat untuk posttest hasil belajar pada materi operasi hitung bilangan cacah, instrumen berupa tes pilihan ganda yang mengukur kemampuan siswa pada materi operasi hitung bilangan cacah yang disesuaikan dengan indikator pencapaian.

Ringkasan hasil pretest dan posttest pada kelompok eksperimen materi operasi hitung bilangan cacah siswa kelas VI SD Negeri Balerejo 1 kemudian ditabulasi dan di olah menggunakan SPSS Versi 24.0 untuk mengatahui ada tidaknya pengaruh yang diberikan terhadap pengggunakan model pembalajaran Inquiry. Adapun hasil prestest dan postest sebagai berikut:

Tabel 1. Hasil prestest dan postest model Inquiri SD Negeri Balerejo 1 Dempet Demak

\begin{tabular}{llcc}
\hline \multirow{2}{*}{ No } & \multirow{2}{*}{ Siswa } & \multicolumn{2}{c}{ Hasil Tes } \\
\cline { 3 - 4 } & & Prestest & Postest \\
\hline 1 & Adit Firmansah & 61,90 & 78,26 \\
2 & Akbar Aria & 61,90 & 95,65 \\
3 & Ali Maftukhin & 57,14 & 78,26 \\
4 & Ifa Millati M & 52,38 & 86,96 \\
5 & Kelvin Aditia R & 57,14 & 82,61 \\
6 & Khoirul Anwar & 52,38 & 73,91 \\
7 & M. Alfu Niam & 61,90 & 60,87 \\
8 & M. Dafa Rizkya & 52,38 & 86,96 \\
9 & M. Yasin Yusuf & 38,10 & 69,57 \\
10 & Niswatul Ulya & 57,14 & 69,57 \\
11 & Resti Oktavia P & 33,33 & 82,61 \\
12 & Rikha Ayu P & 57,14 & 78,26 \\
13 & Saelin Nihlah & 47,62 & 69,57 \\
14 & Septi Indah R & 57,14 & 73,91 \\
15 & Tsania Rahma & 52,38 & 86,96 \\
16 & Fina Tazkiya & 47,62 & 56,52 \\
17 & Azka Karima F & 61,90 & 60,87 \\
18 & Fitfiyana Ulya & 47,62 & 78,26 \\
19 & Khoirul Umam & 61,90 & 69,57 \\
20 & M. Khamdun & 33,33 & 78,26 \\
21 & M. Khoirur R & 66,67 & 78,26 \\
22 & M. Bayu S & 42,86 & 60,87
\end{tabular}




\begin{tabular}{llll}
23 & M. Aslamu F & 42,86 & 60,87 \\
24 & Mustika S.K & 57,14 & 86,96 \\
25 & Robikatul A & 61,90 & 69,57 \\
26 & Syafa'atul M & 57,14 & 65,22 \\
27 & Sofwatun Nisa & 52,38 & 91,30 \\
28 & Suci Rahma & 57,14 & 82,61 \\
29 & Shelfiana S & 57,14 & 65,22 \\
30 & Qudrotun Nada & 52,38 & 73,91 \\
31 & Ainul Yaqin & 57,14 & 69,57 \\
32 & A. Coirul Faiz & 52,38 & 60,87 \\
33 & Adila Dwi & 38,10 & 86,96 \\
\hline Rata-Rata & 52,87 & 74,93 \\
\hline
\end{tabular}

Selanjutnya hasil perhitungan statistik dengan menggunakan program spss for windows 24 untuk postest pretest kelas Inquiri dapat dilihat sebagai berikut:

Tabel 2. Deskriptif Statistik Kelas Model Inquiry

\begin{tabular}{lccccc}
\hline \multicolumn{5}{c}{ Descriptive Statistics } \\
\hline \multicolumn{1}{c}{ Kelas } & $\mathrm{N}$ & $\begin{array}{c}\text { Mini } \\
\text { mum }\end{array}$ & $\begin{array}{c}\text { Maximu } \\
\mathrm{m}\end{array}$ & Mean & $\begin{array}{c}\text { Std. } \\
\text { Deviation }\end{array}$ \\
\hline $\begin{array}{l}\text { pretest } \\
\text { model }\end{array}$ & 33 & 33.00 & 67.00 & 52.8788 & 8.61234 \\
$\begin{array}{l}\text { Inquiry } \\
\text { Posttest } \\
\text { model }\end{array}$ & 33 & 57.00 & 96.00 & 74.9394 & 10.18559 \\
$\begin{array}{l}\text { Inquiry } \\
\text { Valid N } \\
\text { (listwise) }\end{array}$ & 33 & & & & \\
\hline
\end{tabular}

Sumber: Output SPSS Versi. 24.0

Berdasarkan ouput SPPS dapat dijelaskan bahwa pada pretest kelas eksperimen model inquiry yaitu kelas VI di SD Negeri Balerejo 1 mendapat nilai minimum 33.00 sedangkan nilai maksimum 67.00 dan mean atau rata-rata 52.87, Standar deviasi 8.61. pada tes posttest kelas mendapatkan nilai ratarata/ mean sebesar 74,93, standar deviasi 10,185, nilai minimum 57, dan nilai maksimum 96.

\section{Hasil Pelaksanan Pre-test dan Post-test Kelas dengan Pembelajaran konvensional}

Pada kelas konvensional yaitu di SD Negeri Brakas dilaksanakan pada tanggal 6 , tanggal 10, tanggal 13 dan tanggal 17 bulan Februari 2020 dengan empat kali pertemuan yaitu pertemuan pertama memberikan prestest untuk mengetahui kemampuan awal siswa, kemudian pertemuan kedua dan ketiga untuk perlakuan model pembelajaran konvensional dan pertemuan ke empat untuk posttest hasil belajar pada materi operasi hitung bilangan cacah, instrumen berupa tes pilihan ganda yang mengukur kemampuan siswa pada materi operasi hitung bilangan cacah yang disesuaikan dengan indikator pencapaian. Ringkasan hasil pretest dan posttest materi operasi hitung bilangan cacah pada kelompok konvensional kelas VI SD Negeri Brakas Dempet Demak disajikan dalam bentuk tabel sebagai berikut:

Tabel 3. Hasil prestest dan postest model Konvensional SD Negeri Brakas Dempet.

\begin{tabular}{clcc}
\hline \multirow{2}{*}{ No } & \multicolumn{1}{c}{ Siswa } & \multicolumn{2}{c}{ Hasil Tes } \\
\cline { 3 - 4 } & & Prestest & Postest \\
\hline 1 & A Rizqi Prasetyo & 42,86 & 78,26 \\
2 & Akbar Nuzulul F & 57,14 & 69,57 \\
3 & Alfi Nurin Nazil & 47,62 & 86,96 \\
4 & Bagas Cahyo N & 42,86 & 78,26 \\
5 & Choerul Mukmin & 52,38 & 65,22 \\
6 & Daffa Ibnu Hafid & 61,90 & 73,91 \\
7 & Eka Dimas Adit & 57,14 & 65,22 \\
8 & Fitri Cahyani & 57,14 & 69,57 \\
9 & Maulin Hilda & 42,86 & 65,22 \\
10 & Mahardika W & 61,90 & 73,91 \\
11 & M Robith Al & 38,10 & 69,57 \\
12 & M Najih & 47,62 & 69,57 \\
13 & M Yusni Fadhil & 47,62 & 73,91 \\
14 & Naila Karina P & 47,62 & 91,30 \\
15 & Nasiftul Ainur & 52,38 & 65,22 \\
16 & Rafa Ramadhani & 52,38 & 65,22 \\
17 & Sabila Yasaroh & 57,14 & 73,91 \\
18 & Syafaatur R & 52,38 & 60,87 \\
19 & A. Asyroful M & 42,86 & 69,57 \\
20 & A. Naufal Kur. & 33,33 & 56,52 \\
21 & Alisa Kharisma & 52,38 & 65,22 \\
22 & Kafa Akmal P & 52,38 & 65,22 \\
23 & M. Hasan Anwar & 52,38 & 73,91 \\
24 & M. Taufiqul H & 52,38 & 91,30 \\
25 & M. Rizqiya Arif & 47,62 & 86,96 \\
26 & Rizky Kurnia P & 47,62 & 60,87 \\
27 & Rico Irawan & 33,33 & 56,52 \\
28 & Rizky Stiawan & 57,14 & 60,87 \\
29 & Syarif Hidayat & 57,14 & 73,91 \\
30 & A. Khoirul Zaqi & 61,90 & 65,22 \\
31 & Andik Saputra & 47,62 & 82,61 \\
32 & Dimas Supriya & 66,67 & 65,22 \\
33 & Indra Lukman & 76,19 & 78,26 \\
34 & M. Arya Sukma & 66,67 & 78,26 \\
35 & M. Khoirul & 38,10 & 91,30 \\
\hline & Rata-Rata & 51,56 & 71,93 \\
\hline & & & \\
& & &
\end{tabular}

Selanjutnya hasil perhitungan statistik dengan menggunakan program spss for windows 24 untuk postest pretest kelas Konvensional dapat dilihat sebagai berikut:

Tabel 4. Deskriptif Statistik Kelas Konvensional 


\begin{tabular}{lccccc}
\hline \multicolumn{5}{c}{ Descriptive Statistics } \\
\hline & $\mathrm{N}$ & $\begin{array}{l}\text { Mini } \\
\text { mum }\end{array}$ & $\begin{array}{c}\text { Maxi } \\
\text { mum }\end{array}$ & Mean & $\begin{array}{c}\text { Std. } \\
\text { Deviation }\end{array}$ \\
\hline $\begin{array}{l}\text { Pretest } \\
\begin{array}{l}\text { Konven- } \\
\text { sional }\end{array}\end{array}$ & 35 & 33.00 & 76.00 & 51.5429 & 9.42257 \\
$\begin{array}{l}\text { Posttest } \\
\begin{array}{l}\text { Konvens } \\
\text {-ional }\end{array}\end{array}$ & 35 & 57.00 & 91.00 & 71.9429 & 9.54230 \\
$\begin{array}{l}\text { Valid N } \\
\text { (listwise) }\end{array}$ & 35 & & & & \\
\hline
\end{tabular}

Sumber: Output SPSS Versi. 24.0

Berdasarkan ouput SPPS dapat dijelaskan bahwa pada pretest kelas konvensional yaitu kelas VI di SD Negeri Brakas Dempet mendapat nilai minimum 33.00 sedangkan nilai maksimum 76.00 dan mean atau rata-rata 51.54, Standr deviasi 9.42. pada tes posttest mendapat nilai rata-rata/ mean sebesar 71.94, standar deviasi 9.542, nilai minimum 57, dan nilai maksimum 91.

Hasil pretest dan postest siswa pada kelas VI kelompok inquiry maupun konvensional digambarkan pada grafik di bawah ini:

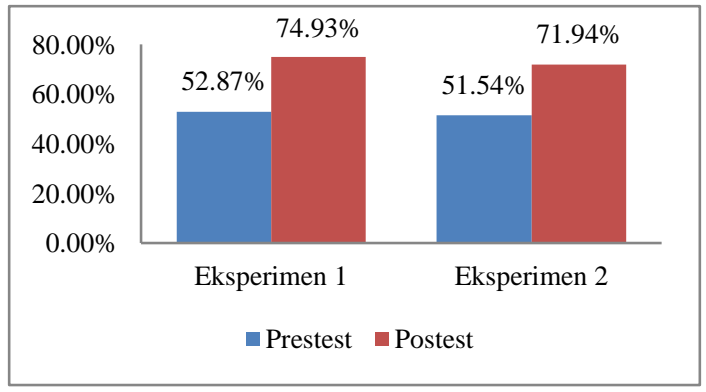

Gambar 1. Hasil pretest dan postest siswa pada kelas VI kelompok inquiry dan konvensional

\section{Analisis Data}

\section{Uji Normalitas}

Uji normalitas dilakukan untuk mengetahui apakah sampel yang diambil dalam penelitian berdistribusi normal atau tidak dan adapun uji normalitas data yang digunakan dalam penelitian ini adalah uji normalitas Kolmogorov-Smirnova dan uji Shapiro-Wilk, dimana keputusan uji sebagai berikut:

$\mathrm{H} 0=$ Sampel berasal dari populasi berdistribusi normal.

$\mathrm{H} 1=$ Sampel tidak berasalah dari populasi berdistribusi normal
Data hasil belajar materi hitung bilangan cacah dianalisis normalitas dan homogenitas. Untuk uji normalitas menggunakan uji KolmogorovSmirnova dan uji Shapiro-Wilk dengan hasil yang tertera pada tabel menunjukkan bahwa kedua kelompok eksperimen merupakan kelas berasal dari sampel yang terdistribusi normal. Perhitungan uji normalitas dapat dilihat pada tabel di bawah ini:

Tabel 5. Uji Normalitas

\begin{tabular}{|c|c|c|c|c|}
\hline \multicolumn{5}{|c|}{ Tests of Normality } \\
\hline \multirow{6}{*}{$\begin{array}{l}\text { hasil } \\
\text { belajar } \\
\text { siswa }\end{array}$} & \multirow{2}{*}{ Kelas } & $\begin{array}{l}\text { Kolmoge } \\
\text { Smirnc }\end{array}$ & $\begin{array}{l}\text { rov- } \\
\text { va }\end{array}$ & Shapiro-Wilk \\
\hline & & $\underset{\text { tic }}{\text { Statis }}$ Df & Sig. & $\underset{\text { tic }}{\text { Statis }}$ Df Sig. \\
\hline & $\begin{array}{l}\text { pretest } \\
\text { Inquiry }\end{array}$ & .19933 & .095 & .906 33.081 \\
\hline & $\begin{array}{l}\text { postest } \\
\text { Inquiry }\end{array}$ & .11033 & $.200^{*}$ & .95833 .226 \\
\hline & $\begin{array}{l}\text { prestest } \\
\text { konven } \\
\text { sional }\end{array}$ & .13835 & .090 & .96935 .412 \\
\hline & $\begin{array}{l}\text { posttest } \\
\text { konven } \\
\text { sional }\end{array}$ & .16735 & .075 & .92835 .125 \\
\hline \multicolumn{5}{|c|}{$\begin{array}{l}\text { a. Lilliefors } \\
\text { Significance } \\
\text { Correction }\end{array}$} \\
\hline \multicolumn{5}{|c|}{$\begin{array}{l}* \text { This is a lower } \\
\text { bound of the true } \\
\text { significance. }\end{array}$} \\
\hline
\end{tabular}

Sumber: Output SPSS Versi 24.0

Hasil uji normalitas data hasil belajar materi hitung bilangan cacah yang tercatat dalam tabel di atas, tampak bahwa pada taraf signifikansi $5 \%$ atau 0,05 . Nilai signifikansi lebih besar dari pada 0.05 pada taraf signifikansi 5\% sehingga hipotesis nol (H0) untuk setiap kelas diterima. Dengan demikian disimpulkan bahwa data pada setiap kelas berasal dari populasi yang berdistribusi normal. Asumsi kenormalan ini diperlukan karena jika kenormalan tidak terpenuhi, keputusan pengujian hipotesis (Uji t-tes) yang diperoleh menjadi tidak sah.

Adapun rekapitulasi hasi uji normalitas dalam penelitian ini baik pada kelas inquiry maupun kelas konvensional akan disajikan pada tabel di bawah ini:

Tabel 6. Rekapitulasi Uji Normalitas 


\begin{tabular}{lccc}
\hline \multicolumn{1}{c}{ Kelas } & $\begin{array}{c}\text { Nilai } \\
\text { Sig }\end{array}$ & Keputusan & Ket \\
\hline pretest & 0.095 & $0.095>$ & Data \\
inquiry & & 0.05 & Normal \\
postest & 0.200 & $0.200>$ & Data \\
inquiry & & 0.05 & Normal \\
prestest & 0.090 & $0.090>$ & Data \\
konvensional & & 0.05 & Normal \\
posttest & 0.075 & $0.075>$ & Data \\
konvensional & 0.05 & Normal \\
\hline
\end{tabular}

\section{Uji Homogenitas}

Hasil tes pada materi hitung bilangan cacah peserta didik selanjutnya dilihat homogenitasnya , uji yang digunakan untuk menentukan homogenitas yakni uji Bartlett yang hasil perhitungannya ditunjukkan pada tabel 2 yang digunakan untuk mengukur apakah kedua kelas berasal dari populasi yang homogen artinya kemampuan semua peserta didik sama. Uji selanjutnya yaitu uji homogenitas uji tersebut berfungsi untuk melihat kehomogenan dari kedua kelas Inquiry dan kelas konvensional atau kedua kelas berasal dari populasi yang homogen atau sama atau tidak. Data hasil perhitungan uji homogenitas kedua kelas eksperimen, yaitu kelas Inquiri dan kelas Konvensional diperoleh hasil seperti tersaji dalam Tabel 7 berikut ini.

Tabel 7. Hasil Uji Homogenitas

\begin{tabular}{|c|c|c|c|c|c|}
\hline & \multicolumn{5}{|c|}{ Test of Homogeneity of Variance } \\
\hline & & $\begin{array}{l}\text { Levene } \\
\text { Statistic }\end{array}$ & df1 & df 2 & Sig. \\
\hline \multirow{4}{*}{$\begin{array}{l}\text { hasil } \\
\text { belajar } \\
\text { siswa }\end{array}$} & $\begin{array}{l}\text { Based on } \\
\text { Mean }\end{array}$ & .673 & 3 & 132 & .570 \\
\hline & $\begin{array}{l}\text { Based on } \\
\text { Median }\end{array}$ & .589 & 3 & 132 & .623 \\
\hline & $\begin{array}{l}\text { Based on } \\
\text { Median and } \\
\text { with adjusted } \\
\text { df }\end{array}$ & .589 & 3 & $\begin{array}{r}128 . \\
967\end{array}$ & .624 \\
\hline & $\begin{array}{l}\text { Based on } \\
\text { trimmed } \\
\text { mean }\end{array}$ & .666 & 3 & 132 & .574 \\
\hline
\end{tabular}

Sumber: Outuput SPSS Versi 24.0

Berdasarkan hasil output SPSS diketahui bahwa hasil nilai signifikansi (sig) Based on Mean adalah sebesar $0.570>0.05$ pada tarap 5\% sehingga dapat disimpulkan bahwa varians data post-test maupun pre-test pada kelas inquiry dan konvensional adalah sama atau homogen. Dengan demikian maka salah satu syarat dari uji independent sampel $t$ test terpenuhi.

\section{Uji Kesamaan Rata-rata}

Uji kesamaan rata-rata dilakukan untuk mengetahui apakah kedua kelas sampel berangkat dari kondisi rata-rata yang sama atau tidak. Hasil analisis uji kesamaan rata-rata data nilai tes hasil belajar peserta didik sebelum dilakukan pembelajaran pada kelas inquiry dan konvensional dengan menggunakan One-Way Anova dapat dilihat pada Tabel 8 berikut:

Tabel 8. Hasil Uji Kesamaan Rata-Rata Hasil Belajar (pretest)

\begin{tabular}{lccccc}
\hline \multicolumn{5}{c}{ ANOVA } \\
\hline Kelas & $\begin{array}{l}\text { Sum of } \\
\text { Squares }\end{array}$ & Df & Mean & & \\
& Squar & F & Sig. \\
\hline Between & 1.402 & 8 & .175 & .663 & .721 \\
Groups & & & & & \\
Within & 15.583 & 59 & .264 & & \\
Groups & & & & & \\
\hline Total & 16.985 & 67 & & & \\
\hline
\end{tabular}

Sumber: Out put SPSS Versi 24.0

Berdasarkan hasil analisis uji kesamaan ratarata data nilai hasil belajar peserta didik sebelum dilakukan pembelajaran pada kelas inquiry dan konvensional dengan menggunakan One-Way Anova pada tabel di atas, diperoleh nilai signifikansi hasil belajar sebesar $0,721>0,05$, sehingga dapat disimpulkan bahwa kedua kelas tersebut (inquiry dan konvensional), memiliki nilai rata-rata yang sama atau kemampuan awal peserta didik kelas inquiry tidak lebih baik dari pada kelas konvensional.

Dengan demikian, diketahui bahwa kemampuan awal peserta didik kelas inqury dan kelas konvensional sama atau tidak berbeda secara signifikan, maka dapat disimpulkan bahwa kedua kelas sampel telah memenuhi syarat untuk diberi perlakuan, yaitu memberikan pembelajaran di kelas inquiry dan pada kelas konvensional dengan model 
pembelajaran Inquiry, yang kemudian akan dilakukan penelitian untuk mengetahui tingkat perbedaan pengaruh dari perlakuan tersebut.

Sedangkan hasil analisis uji kesamaan ratarata data nilai hasil belajar peserta didik setelah dilakukan pembelajaran pada kelas inquiry di kelas VI SD Negeri Balerejo 1 dan konvensional di SD Negeri Brakas. maka uji kesamaan rata-rata menggunakan model One-Way Anova dapat dilihat pada Tabel 9 berikut :

Tabel 9. Hasil Uji Kesamaan Rata-Rata Hasil Belajar (postest)

\begin{tabular}{|c|c|c|c|c|c|}
\hline \multicolumn{6}{|c|}{ ANOVA } \\
\hline \multirow{2}{*}{$\overline{\text { kelas }}$} & & & & & \\
\hline & $\begin{array}{l}\text { Sum of } \\
\text { Squares }\end{array}$ & Df & $\begin{array}{l}\text { Mean } \\
\text { Square }\end{array}$ & $\mathrm{F}$ & Sig. \\
\hline $\begin{array}{l}\text { Between } \\
\text { Groups }\end{array}$ & 3.207 & 12 & 267 & 1.067 & .000 \\
\hline $\begin{array}{l}\text { Within } \\
\text { Groups }\end{array}$ & 13.778 & 55 & .251 & & \\
\hline Total & 16.985 & 67 & & & \\
\hline
\end{tabular}

Sumber: Ouptut SPSS Versi 24.0

Berdasarkan hasil analisis uji kesamaan ratarata data nilai hasil belajar peserta didik setelah dilakukan pembelajaran pada kelas inquiry dan kelas konvensional dengan menggunakan One-Way Anova pada tabel di atas, diperoleh nilai signifikansi hasil belajar sebesar 0,000 $<0,05$, sehingga dapat disimpulkan bahwa kedua kelas tersebut (inquiry dan konvensional), memiliki rata-rata yang tidak sama atau tidak identik (berbeda secara signifikan). Uji kesamaan rata-rata untuk lebih memberikan pemahaman dijelaskan pada Tabel 10 di bawah ini:

Tabel 10. Rekapitulasi Uji Kesamaan

\begin{tabular}{|c|c|c|c|}
\hline $\begin{array}{c}\text { Kate- } \\
\text { gori }\end{array}$ & $\begin{array}{l}\text { Nilai } \\
\text { Sig }\end{array}$ & Keputusan & Keterangan \\
\hline $\begin{array}{l}\text { Pre- } \\
\text { test }\end{array}$ & 0.721 & $\begin{array}{l}0.721> \\
0.05\end{array}$ & $\begin{array}{l}\text { Kedua kelas } \\
\text { eksperimen } \\
\text { memiliki nilai } \\
\text { rata-rata sama } \\
\text { atau } \\
\text { kemampuan }\end{array}$ \\
\hline $\begin{array}{l}\text { Post- } \\
\text { test }\end{array}$ & 0.000 & $\begin{array}{l}0.000< \\
0.05\end{array}$ & $\begin{array}{l}\text { awal siswa } \\
\text { sama. } \\
\text { Kedua kelas } \\
\text { eksperimen } \\
\text { memiliki nilai } \\
\text { rata-rata tidak }\end{array}$ \\
\hline
\end{tabular}

sama atau
kemampuan
siswa setelah
diberikan
perlakukan
dengan model
pembelajaran
yang berbeda
memiliki
kemampuan
yang berbeda.

\section{Uji Pembeda}

Apabila pada nilai rata-rata hasil belajar setelah dilakukan pembelajaran diketahui terdapat perbedaan rata-rata hasil belajar peserta didik kelas inquiry dan kelas konvensional maka selanjutnya dilaksanakan uji beda dengan menggunakan uji-t paired-samples t test untuk mengetahui apakah ratarata hasil belajar kelas inquiry lebih baik dari kelas konvensional atau sebaliknya.

Hasil analisis uji t data nilai hasil belajar peserta didik setelah dilakukan pembelajaran pada kelas inquiry dengan cara menggunakan pairedsamples $t$ test dapat dilihat pada Tabel 11 berikut:

Tabel 11. Paired Samples Test Hasil Belajar Peserta Didik

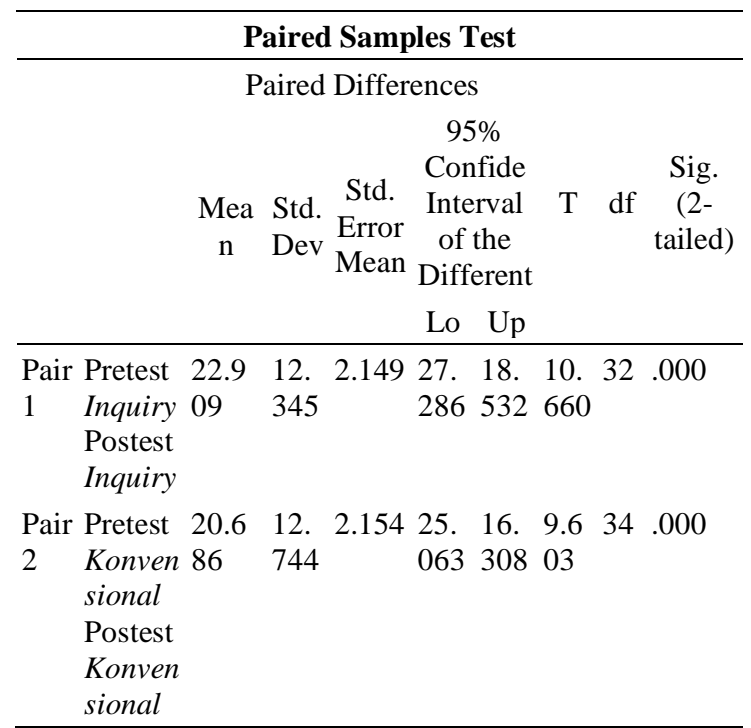

Sumber: Output SPSS Versi 24.0

Berdasarkan hasil paired samples test Hasil Belajar Peserta Didik dapat diambil kesimpulan bahwa:

1. Berdasarkan output Pair 1 diperoleh nilai Sig. (2tailed) diperoleh $0.000<0.05$, atau t-hitung $10.660>$ t-tabel 1.69236 maka dapat 
disimpulkan bahwa ada perbedaan rata-rata hasil belajar siswa untu pre-test kelas inquiry dengan post-test kelas inquiry. Dengan demikian maka dapat diambil kesimpulan bahwa ada pengaruh model Inquiry terhadap hasil belajar bilangan operasi hitung bilangan cacah kelas VI SD Negeri Balerejo 1 Dempet Demak.

2. Berdasarkan output Pair 2 diperoleh nilai Sig. (2tailed) diperoleh $0.000<0.05$ atau t-hitung 9.603 $>$ t-tabel 1.68957, maka dapat disimpulkan bahwa ada perbedaan rata-rata hasil belajar siswa untu pre-test kelas konvensional dengan post-test kelas konvensional. Dengan demikian maka dapat diambil kesimpulan bahwa ada pengaruh model pembelajaran Konvensional terhadap hasil belajar bilangan operasi hitung bilangan cacah kelas VI SD Negeri Brakas Dempet Demak.

3. Besar pengaruh model pembelajaran Inquiry terhadap hasil belajar bilangan operasi hitung bilangan cacah kelas VI di SD Negeri Balerejo 1 sebesar 22,91 dan pengaruh model konvensional terhadap hasil belajar bilangan operasi hitung bilangan cacah kelas VI di SD Negeri Brakas adalah sebesar 20.69. hal ini berdasarkan diketahui berdasarkan nilai mean (rata-rata) postest diambil rata-rata postest dalam tabel paired sampel statistics pada Tabel 12 di bawah ini.

Tabel 12. Rekap Paired Samples Statistics

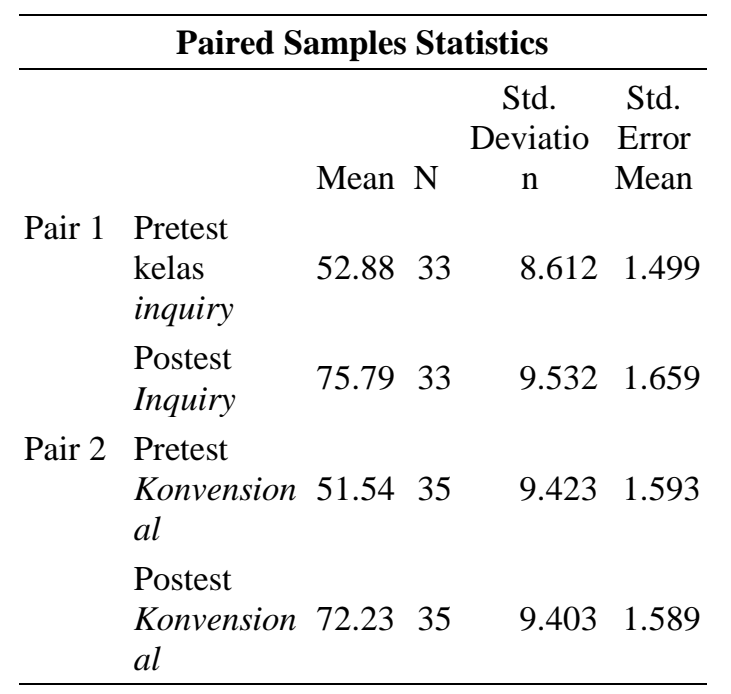

Sumber : Output SPSS Versi 24.0

\section{Uji Indeks Gain}

Perhitungan indeks gain dilakukan sebagai uji pendukung untuk mengetahui besar peningkatan hasil belajar peserta didik kelas inquiry dan kelas konvensional yang menggunakan model pembelajaran inquiry. Perbedaan peningkatan hasil belajar kelas pada kelas inquiry dan kelas konvensional diketahui dengan penghitungan indeks gain. Hasil perhitungan indeks gain hasil belajar peserta didik dapat dilihat pada Tabel 13 berikut:

Tabel 13. Perhitungan Indeks Gain Hasil Belajar Peserta Didik Kelas Inquiry

\begin{tabular}{|c|c|c|c|c|}
\hline \multirow[b]{2}{*}{$\mathrm{NO}$} & \multicolumn{2}{|c|}{ INQUIRY } & \multirow[b]{2}{*}{$\begin{array}{c}\mathrm{N} \\
\text { Gain }\end{array}$} & \multirow[b]{2}{*}{ Kriteria } \\
\hline & $\begin{array}{c}\text { PRE } \\
\text { TEST }\end{array}$ & $\begin{array}{c}\text { POS } \\
\text { TEST }\end{array}$ & & \\
\hline 1 & 62 & 78 & 0,42 & Sedang \\
\hline 2 & 62 & 96 & 0,89 & Tinggi \\
\hline 3 & 57 & 78 & 0,49 & Sedang \\
\hline 4 & 52 & 87 & 0,73 & Tinggi \\
\hline 5 & 57 & 83 & 0,60 & Sedang \\
\hline 6 & 52 & 74 & 0,46 & Sedang \\
\hline 7 & 62 & 75 & 0,34 & Sedang \\
\hline 8 & 52 & 87 & 0,73 & Tinggi \\
\hline 9 & 38 & 70 & 0,52 & Sedang \\
\hline 10 & 57 & 70 & 0,30 & Sedang \\
\hline 11 & 33 & 83 & 0,75 & Tinggi \\
\hline 12 & 57 & 78 & 0,49 & Sedang \\
\hline 13 & 48 & 70 & 0,42 & Sedang \\
\hline 14 & 57 & 74 & 0,40 & Sedang \\
\hline 15 & 52 & 87 & 0,73 & Tinggi \\
\hline 16 & 48 & 57 & 0,17 & Rendah \\
\hline 17 & 62 & 75 & 0,34 & Sedang \\
\hline 18 & 48 & 78 & 0,36 & Sedang \\
\hline 19 & 62 & 70 & 0,21 & Rendah \\
\hline 20 & 33 & 78 & 0,67 & Sedang \\
\hline 21 & 67 & 78 & 0,33 & Sedang \\
\hline 22 & 43 & 61 & 0,32 & Sedang \\
\hline 23 & 43 & 61 & 0,32 & Sedang \\
\hline 24 & 57 & 87 & 0,70 & Sedang \\
\hline 25 & 62 & 70 & 0,21 & Rendah \\
\hline 26 & 57 & 65 & 0,19 & Rendah \\
\hline 27 & 52 & 91 & 0,81 & Tinggi \\
\hline 28 & 57 & 83 & 0,60 & Sedang \\
\hline 29 & 57 & 65 & 0,19 & Rendah \\
\hline 30 & 52 & 74 & 0,46 & Sedang \\
\hline 31 & 57 & 70 & 0,30 & Sedang \\
\hline 32 & 52 & 61 & 0,19 & Rendah \\
\hline 33 & 38 & 87 & 0,79 & Tinggi \\
\hline
\end{tabular}

Berdasarkan tabel di atas, diketahui bahwa indeks gain peningkatan hasil belajar peserta didik kelas inquiry yang termasuk kategori tinggi sebanyak 7 peserta didik atau $21,21 \%$, yang termasuk kategori peningkatan hasil belajar sedang sebanyak 20 peserta didik atau $60,61 \%$, dan yang termasuk kategori mengalami peningkatan hasil 
belajar rendah sebanyak 6 peserta didik atau $18,18 \%$. Lebih jelasnya hasil nilai indeks Gain Inquiry dibuat disajikan dalam bentuk Tabel 14 di bawah ini:

Tabel 14. Rekapitulasi nilai Indeks Gain Inquiry

\begin{tabular}{cccc}
\hline No & Kategori & Siswa & $\%$ \\
\hline 1 & Tinggi & 7 & 21,21 \\
2 & Sedang & 20 & 60,61 \\
3 & Rendah & 6 & 18,18 \\
\hline & Jumlah & 33 & $100 \%$ \\
\hline
\end{tabular}

Berdasarkan tabel di atas dapat disusun grafik peningkatan hasil belajar siswa pada kelas inquiry di Gambar 2:



Gambar 2. Peningkatan hasil belajar siswa berdasarkan nilai indeks gain pada kelas inquiry.

Adapun statistik deskriptifnya indeks gain pada inquiry disajikan dari output SPSS Versi 24.0 pada table 15 berikut ini:

Tabel 15. Statistik Deskriptif N Gain Kelas Inquiry

\begin{tabular}{|c|c|c|c|c|}
\hline \multicolumn{5}{|c|}{ Descriptives } \\
\hline \multicolumn{3}{|c|}{ kelas } & Statistic & $\begin{array}{l}\text { Std. } \\
\text { Error }\end{array}$ \\
\hline \multirow[t]{13}{*}{$\begin{array}{l}\text { N Gain } \\
\text { Persen }\end{array}$} & inquiry & Mean & 47.404 & $\begin{array}{r}3.70 \\
567\end{array}$ \\
\hline & & $\begin{array}{ll}95 \% & \text { Lower } \\
\text { Confid } & \text { Bound }\end{array}$ & 39.856 & \\
\hline & & $\begin{array}{l}\text { ence Upper } \\
\text { Interval Bound } \\
\text { for } \\
\text { Mean }\end{array}$ & 54.952 & \\
\hline & & $\begin{array}{l}5 \% \text { Trimmed } \\
\text { Mean }\end{array}$ & 46.890 & \\
\hline & & Median & 45.833 & \\
\hline & & Variance & 453.15 & \\
\hline & & Std. Deviation & 2.1287 & \\
\hline & & Minimum & 17.31 & \\
\hline & & Maximum & 89.47 & \\
\hline & & Range & 72.17 & \\
\hline & & $\begin{array}{l}\text { Interquartile } \\
\text { Range }\end{array}$ & 37.56 & \\
\hline & & Skewness & .269 & .409 \\
\hline & & Kurtosis & -1.104 & .798 \\
\hline
\end{tabular}

Sumber: Output SPSS Versi 24.0

Berdasarkan statistik deskriptif di atas diketahui bahwa pada kelas inquiry hasil pembelajaran di kelas VI SD Negeri Balerejo 1 Dempet Demak rata-rata skor mendapatkan nilai 47.4042, standar deviation (tingkat penyimpangan) sebanyak 2.12875, sedangkan Std. error of mean sebanyak 3.70567 range (rentang nilai) 72.17, dengan nilai terendah 17.31 nilai tertinggi 89.47, nilai tengah (median) sebanyak 45.8333 .

Adapun hasil perhitungan indeks gain hasil belajar peserta didik kelas konvensional dijelaskan pada Tabel 16 di bawah ini:

Tabel 16. Perhitungan Indeks Gain Hasil Belajar Peserta Didik Kelas Konvensional

\begin{tabular}{ccccc}
\hline \multirow{4}{*}{ NO } & \multicolumn{2}{c}{ KONVENSIONAL } & $\mathrm{N}$ & \\
& PRE & POS & Gain & Kriteria \\
& TEST & TEST & & \\
\hline 1 & 43 & 78 & 0,61 & Sedang \\
2 & 57 & 70 & 0,30 & Sedang \\
3 & 48 & 87 & 0,75 & Tinggi \\
4 & 43 & 78 & 0,61 & Sedang \\
5 & 52 & 65 & 0,27 & Rendah \\
6 & 62 & 74 & 0,32 & Sedang \\
7 & 57 & 65 & 0,19 & Rendah \\
8 & 57 & 70 & 0,30 & Sedang \\
9 & 43 & 65 & 0,39 & Sedang
\end{tabular}




\begin{tabular}{lllll}
10 & 62 & 74 & 0,32 & Sedang \\
11 & 38 & 70 & 0,52 & Sedang \\
12 & 48 & 70 & 0,42 & Sedang \\
13 & 48 & 74 & 0,51 & Sedang \\
14 & 48 & 91 & 0,83 & Tinggi \\
15 & 52 & 65 & 0,27 & Rendah \\
16 & 52 & 65 & 0,27 & Rendah \\
17 & 57 & 74 & 0,39 & Sedang \\
18 & 52 & 61 & 0,19 & Rendah \\
19 & 43 & 70 & 0,47 & Sedang \\
20 & 33 & 57 & 0,36 & Sedang \\
21 & 52 & 65 & 0,27 & Rendah \\
22 & 52 & 65 & 0,27 & Rendah \\
23 & 52 & 74 & 0,46 & Sedang \\
24 & 52 & 91 & 0,81 & Tinggi \\
25 & 48 & 87 & 0,75 & Tinggi \\
26 & 48 & 61 & 0,25 & Rendah \\
27 & 33 & 57 & 0,36 & Sedang \\
28 & 57 & 61 & 0,09 & Rendah \\
29 & 57 & 74 & 0,40 & Sedang \\
30 & 62 & 69 & 0,18 & Rendah \\
31 & 48 & 83 & 0,67 & Sedang \\
32 & 67 & 71 & 0,12 & Rendah \\
33 & 76 & 78 & 0,08 & Rendah \\
34 & 67 & 78 & 0,33 & Sedang \\
35 & 38 & 91 & 0,85 & Tinggi \\
\hline & & & & \\
\hline
\end{tabular}

Sedangkan indeks gain peningkatan hasil belajar materi operasi hitung bilangan cacah peserta didik kelas konvensional di SD Negeri Brakas Dempet yang termasuk terjadi peningkatan hasil belajar kategori tinggi ada 5 atau 14,29\% pada peningatan hasil belajar kategori sedang sebanyak 18 peserta didik atau 51,43 dan yang termasuk peningkatan hasil belajar kategori rendah sebanyak 12 peserta didik atau 34,29\%. Lebih jelasnya hasil nilai indeks Gain Konvensional dibuat disajikan dalam bentuk Tabel 17 di bawah ini:

Tabel 17 . Rekapitulasi nilai Indeks Gain Konvensional

\begin{tabular}{cccc} 
No & Kategori & Siswa & $\%$ \\
\hline 1 & Tinggi & 5 & 14,29 \\
2 & Sedang & 18 & 51,43 \\
3 & Rendah & 12 & 34,29 \\
\hline & Jumlah & 35 & $100 \%$ \\
\hline
\end{tabular}

Berdasarkan tabel di atas dapat disusun grafik peningkatan hasil belajar siswa pada kelas konvensional pada Gambar 3 di bawah ini:



Gambar Peningkatan hasil belajar siswa berdasarkan nilai Indeks Gain pada kelas konvensional.

Gambar 3. Grafik peningkatan hasil belajar siswa pada kelas konvension

Adapun statistik deskriptifnya disajikan dari output SPSS Versi 24.0 pada Tabel 18 berikut ini:

Tabel 18. Statistik Deskriptif N Gain Kelas Konvensional

\begin{tabular}{|c|c|c|c|c|}
\hline \multicolumn{5}{|c|}{ Descriptives } \\
\hline \multirow{22}{*}{$\begin{array}{l}\mathrm{N} \quad \text { konvens } \\
\text { Gain_ional } \\
\text { persen }\end{array}$} & & & & Std. \\
\hline & Kelas & & Statistic & Error \\
\hline & Mean & & & 3.61 \\
\hline & & & אנד.J & 999 \\
\hline & $95 \%$ & Lower & 33182 & \\
\hline & Confider & Bound & & \\
\hline & ce & Upper & & \\
\hline & Interval & Bound & 47.896 & \\
\hline & for Mear & & & \\
\hline & $5 \%$ Trim & ned & & \\
\hline & Mean & & & \\
\hline & Median & & 35.820 & \\
\hline & Variance & & 458.65 & \\
\hline & Std. Dev & ation & 2.1416 & \\
\hline & & & $2 \mathrm{E} 1$ & \\
\hline & Minimur & & 8.33 & \\
\hline & Maximu & & 85.48 & \\
\hline & Range & & 77.15 & \\
\hline & Interqua & & 2453 & \\
\hline & Range & & & \\
\hline & Skewnes & & .687 & .398 \\
\hline & Kurtosis & & -.388 & .778 \\
\hline
\end{tabular}

Sumber: Output SPSS Versi 24.0 
Berdasarkan statistik deskriptif di atas diketahui bahwa pada kelas konvensional hasil pembelajaran di kelas VI SD Negeri Brakas Dempet Demak rata-rata skor mendapatkan nilai 40.5393, standar deviation (tingkat penyimpangan) sebanyak 2.14162, sedangkan Std. error of mean sebanyak 3.61999 range (rentang nilai) 77.15, dengan nilai terendah 8.33 nilai tertinggi 85.48 , nilai tengah (median) sebanyak 35.8209.

Tabel 19. Rekapituilasi nilai N indeks Gain Kelas Inquiry dan Konvensional.

\begin{tabular}{cccccc}
\hline & \multicolumn{2}{c}{ Inquiry } & \multicolumn{2}{c}{ Konvensional } \\
\hline \multirow{2}{*}{ No } & $\begin{array}{c}\text { Kate- } \\
\text { gori }\end{array}$ & Siswa & $\%$ & Siswa & $\%$ \\
\hline 1 & Tinggi & 7 & 21,21 & 5 & 14,29 \\
2 & Sedang & 20 & 60,61 & 18 & 51,43 \\
3 & Rendah & 6 & 18,18 & 12 & 34,29 \\
\hline \multicolumn{2}{c}{ Jumlah } & 33 & $100 \%$ & 35 & $100 \%$ \\
\hline
\end{tabular}

Berdasarkan tabel di atas dapat diketahui bahwa kelas inquiry dengan menggunakan model pembelajaran Inquiri peningkatan hasil belajar lebih banyak dari pada kelas konvensional yang menggunakan model pembelajaran konvensional. Hal tersebut juga di dukung dengan hal ini berdasarkan nilai means hasil posttest inquiry sebesar 74.93 dan posttest konvensional sebesar 71.94. ini menunjukkan bahwa ada selisih perbedaan sebesar 2.99 .

\section{PEMBAHASAN}

\section{Pengaruh model pembelajaran Inquiry terhadap peningkatan hasil belajar siswa pada operasi hitung bilangan cacah di kelas VI Sekolah Dasar.}

\section{Pengertian Model Pembelajaran Inquiry}

Inquiry adalah istilah dalam Bahasa Inggris; ini merupakan suatu teknik atau cara yang digunakan guru untuk mengajar di depan kelas. Teknik yang sangat efektif dalam pembelajaran guru di dalam kelas karena metode inkuiri ini memiliki tujuan agar siswa terangsang oleh tugas, dan aktif mencari serta meneliti sendiri pemecahan masalahnya.

Pendapat lain menyatakan bahwa model pembelajaran inquiry adalah pembelajaran di mana siswa didorong untuk belajar melalui keterlibatan aktif mereka sendiri dengan konsep-konsep dan prinsip-prinsip, dan guru mendorong siswa untuk memiliki pengalaman dan melakukan percobaan yang memungkinkan siswa menemukan prinsiprinsip untuk diri mereka sendiri (Kunandar, 2017:371). Hal tersebut ditujukan untuk membuat siswa berpikir untuk diri mereka sendiri, mengetahui dari suatu proses bukan suatu produk sehingga menjadikan pembelajaran lebih bermakna dan terkenang dalam ingatan siswa.

Menurut Wina Sanjaya (2016) inquiry adalah rangkaian kegiatan pembelajaran yang menekankan pada proses berpikir secara kritis dan analitis untuk mencari dan menemukan sendiri jawaban dari suatu masalah yang dipertanyakan. Proses berpikir itu sendiri biasanya dilakukan melalui tanya jawab antara guru dan siswa. Inquiry menekankan kepada aktivitas siswa secara maksimal untuk mencari dan menemukan, artinya inquiry menempatkan siswa sebagai subyek belajar. Dalam proses pembelajaran, siswa tidak hanya berperan sebagai penerima pelajaran melalui penjelasan dari guru secara verbal, tetapi mereka berperan untuk menemukan sendiri inti dari materi pelajaran itu sendiri. Pembelajaran inquiry bertujuan mengembangkan kemampuan berpikir siswa secara sistematis, logis, dan kritis, atau mengembangkan kemampuan intelektual sebagai proses dari proses mental. Dengan demikian, siswa tak hanya dituntut agar menguasai materi pelajaran, akan tetapi bagaimana mereka dapat menggunakan potensi yang dimilikinya.

Risa Agustin (2014) menjeaskan bahwa dalam model pembelajaran inkuiri terbimbing, penyajian pelajaran diawali dengan penjelasan suatu peristiwa yang penuh teka-teki. Siswa secara individu akan termotivasi menyelesaikan teka-teki yang dihadapkan pada mereka dan membimbing mereka kepada suatu pencarian dan penyelidikan secara disiplin. Inkuiri diharapkan dapat memberikan kesempatan dengan lebih leluasa kepada siswa untuk belajar dan bekerja melalui proses inkuiri sebagaimana seorang ilmuwan atau peneliti bekerja.

Welch mendefinisikan inquiry sebagai proses dimana manusia mencari informasi atau pengertian, maka sering disebut away of thought. Sedangkan Kidsvatter dkk menjelaskan inquiry sebagai model pengajaran dimana guru melibatkan kemampuan berpikir kritis siswa untuk menganalisis dan memecahkan persoalan secara sistematik (Paul Suparno, 2017)

Jadi, model pembelajaran inkuiri merupakan suatu pembelajaran yang menuntut peserta didik menemukan sesuatu dan memecahkan masalah dalam pembelajaran atau penelitian. 
Inkuiri (inquiry) merupakan bagian inti dari kegiatan pembelajaran berbasis kontekstual (Trianto, 2011). Pengetahuan dan keterampilan yang diperoleh siswa diharapkan bukan dari hasil mengingat seperangkat fakta-fakta, tetapi hasil dari menemukan sendiri. Siklus Inquiry terdiri dari:

1. Observasi (Observation);

2. Bertanya (Questioning);

3. Mengajukan dugaan (Hyphotesis);

4. Pengumpulan data (Data gathering);

5. Penyimpulan (Conclussion);

\section{Karakteristik Model Pembelajaran Inqury}

Wina Sanjaya (2016) menjelaskan beberapa karakterisik Ciri utama dalam pembelajaran Inkuiri adalah sebagai berikut:

1. Inkuiri menekankan pada aktivitas siswa secara maksimal untuk mencari dan menemukan. Artinya menempatkan siswa sebagai subjek belajar. Dalam proses belajar tidak hanya menerima melainkan juga menemukan sendiri inti dari materi.

2. Seluruh aktivitas siswa diarahkan untuk mencari dan menemukan jawaban sendiri dari sesuatu yang dipertanyakan, sehingga diharapkan dapat menumbuhkan sikap percaya diri.

3. Tujuan dari pembelajaran inkuiri adalah mengembangkan kemampuan berpikir secara sistematis, logis, dan kritis, atau mengembangkan kemampuan kemampuan intelektual sebagai bagian dari proses mental. Dengan demikian dalam inkuiri siswa tidak hanya dituntut dalam menguasai materi tapi juga bagaimana mereka dapat menggunakan potensi dalam diri.

Menurut Yamin dalam Ely Sarantika (2017) menjelaskan bahwa Kemampuan metode inquiri terbimbing ditunjukkan Melalui pembelajaran kelompok siswa dilatih bekerjasama, berdiskusi, keberanian menyampaiakn pendapat, menghargai pendapat orang lain dan memecahkan masalah bersama-sama.

\section{Kelebihan dan Kelemahan Pembelajaran Inquiry}

Strategi Pembelajaran Inquiry adalah strategi pembelajaran yang menekankan kepada proses mencari dan menemukan. Peran siswa dalam strategi pembelajaran ini adalah mencari dan merumuskan sendiri materi pelajaran, sedangkan guru berperan sebagai fasilitator dan pembimbing siswa untuk belajar. Meskipun demikian pembelajaran ini memiliki kelebihan sekaligus kekurangan diantara kelebihan tersebut adalah:

1. Membantu peserta didik untuk mengembangkan, kesiapan, serta penguasaan keterampilan dalam proses kognitif

2. Peserta didik memperoleh pengetahuan secara individual sehingga dapat dimengerti dan mengendap dalam pikirannya.

3. Dapat membangkitkan motivasi dan gairah belajar peserta didik untuk belajar lebih giat lagi.

4. Memberikan peluang untuk berkembang dan maju sesuai dengan kemampuan dan minat masing masing.

5. Memperkuat dan menambah kepercayaan pada diri sendiri dengan proses menemukan sendiri karena pembelajaran berpusat pada peserta didik dengan peran guru yang sangat terbatas.

Sedangkan kelemahan dari pembelajaran inquiry ini adalah:

1. Siswa harus memiliki kematangan mental, siswa harus berani dan berkeinginan untuk mengetahui keadaan sekitarnya dengan baik

2. Keadaan kelas di kita kenyataanya gemuk jumlah siswanya maka metode ini tidak akan mencapai hasil yang memuaskan

3. Guru dan siswa yang sudah sangat terbiasa dengan PBM gaya lama maka metode ini akan mengecewakan

4. Ada kritik, bahwa proses pengertian saja, kurang memerhatikan perkembangan sikap dan keterampilan bagi siswa. (Hanafiah, Suhana, 2016)

Menurut Wina Sanjaya (2016) kelebihan dan kekurangan metode inquiry ini adalah:

1. Menekankan kepada pengembangan aspek kognitif, afektif, dan psikomotor secara seimbang, sehingga pembelajaran dianggap lebih bermakna.

2. Memberikan ruang kepada siswa untuk belajar sesuai dengan gaya belajar mereka.

3. Dianggap sesuai dengan perkembangan psikologi belajar modern yang menganggap belajar adalah proses perubahan tingkah laku berkat adanya pengalaman.

4. Dapat melayani kebutuhan siswa yang memiliki kemampuan di atas rata-rata. Artinya siswa yang memiliki kemampuan belajar bagus tidak akan terhambat oleh siswa yang lemah dalam belajar.

5. Melatih siswa untuk lebih giat belajar sendiri.

Sedangkan kelemahan dari metode ini adalah:

1. Akan sulit mengontrol kegiatan dan keberhasilan siswa. 
2. Tidak semua materi dapat diterapkan dengan metode ini.

3. Sulit dalam merencanakan pembelajaran karena terbentur dengan kebiasan siswa dalam belajar.

4. Dalam mengimplementasikannya memerlukan waktu yang panjang, sehingga guru sulit menyesuaikannya dengan waktu yang telah ditentukan.

5. Tidak semua guru bisa menerapkan metode ini.

\section{Tahapan Langkah Pembelajaran Inquiry}

Secara umum proses pembelajaran dengan menggunakan metode inquiry, pembelajaran inqury pada prinsipnya berangkat dari asumsi bahwa sejak manusia lahir ke dunia, manusia memiliki dorongan untuk menemukan sendiri pengetahuannya (Wina Sanjaya, 2018). Langkah-langkah dalam pelaksanaan pembelajaran menggunakan Strategi Pembelajaran Inquiry, yakni:

Tabel . Sintak Inquiry

\begin{tabular}{|c|c|}
\hline Tahapan & Kegiatan Guru Di Kelas \\
\hline Tahap 1 & Guru menyajikan kejadian- \\
\hline $\begin{array}{l}\text { Observasi untuk } \\
\text { menemukan } \\
\text { masalah }\end{array}$ & $\begin{array}{l}\text { kejadian atau fenomena } \\
\text { yang memungkinkan siswa } \\
\text { menemukan masalah }\end{array}$ \\
\hline $\begin{array}{l}\text { Tahap } 2 \\
\text { Merumuskan } \\
\text { masalah }\end{array}$ & $\begin{array}{l}\text { Guru membimbing siswa } \\
\text { merumuskan masalah } \\
\text { penelitian berdasarkan } \\
\text { kejadian dan fenomena } \\
\text { yang disajikannya }\end{array}$ \\
\hline $\begin{array}{l}\text { Tahap } 3 \\
\text { Mengajukan } \\
\text { hipotesis }\end{array}$ & $\begin{array}{l}\text { Guru membimbing siswa } \\
\text { untuk mengajukan } \\
\text { hipotesis terhadap masalah } \\
\text { yang telah dirumuskannya }\end{array}$ \\
\hline $\begin{array}{l}\text { Tahap } 4 \\
\text { Merencanakan } \\
\text { pemecahan } \\
\text { masalah } \\
\text { (melalui } \\
\text { eksperimen atau } \\
\text { cara lain) }\end{array}$ & $\begin{array}{l}\text { Guru membimbing siswa } \\
\text { untuk merencanakan } \\
\text { pemecahan masalh, } \\
\text { membantu menyiapkan } \\
\text { alat dan bahan yang } \\
\text { diperlukan dan menyusun } \\
\text { prosedur kerja yang tepat }\end{array}$ \\
\hline $\begin{array}{l}\text { Tahap } 5 \\
\text { Melaksanakan } \\
\text { eksperimen } \\
\text { (atau cara } \\
\text { pemecahan } \\
\text { masalh ) }\end{array}$ & $\begin{array}{l}\text { Selama siswa bekerja, guru } \\
\text { membimbing dan } \\
\text { memfasilitasi }\end{array}$ \\
\hline $\begin{array}{l}\text { Tahap } 6 \\
\text { Melakukan } \\
\text { pengamatan dan } \\
\text { pengumpulan } \\
\text { data }\end{array}$ & $\begin{array}{l}\text { Guru membantu siswa } \\
\text { melakukan pengamatan } \\
\text { tentang hal-hal yang } \\
\text { penting dan membantu } \\
\text { mengumpilkan dan } \\
\text { mengorganisasi data }\end{array}$ \\
\hline
\end{tabular}

Tahap 7
Analisis data
Tahap 8
Penarikan
kesimpulan dan
penemuan

Guru membantu siswa menganalisis data supaya menemukan suatu konsep Guru membimbing siswa mengambil kesimpulan berdasarkan data dan menemukan sendiri konsep yang ingin dijadikan hasil.

Menurut Trianto (2010) bahwa sintakssintaks model pembelajaran inkuiri yaitu sebagai berikut:

1. Merumuskan masalah

2. Merumuskan hipotesis

3. Merancang percobaan

4. Melakukan percobaaan

5. Mengumpulkan dan menganalisis data

6. Membuat kesimpulan

Langkah-langkah metode inquiry menurut Kindsvatter dkk dalam buku Paul Suparno (2017) adalah sebagai berikut:

1. Identifikasi dan klarifikasi persoalan.

Langkah awal adalah menentukan persoalan yang ingin didalami atau dipecahkan dengan metode inquiry. Persoalan dapat disiapkan atau diajukan oleh guru. Sebaiknya persoalan yang ingin dipecahkan disiapkan sebelum mulai pelajaran. Persoalan sendiri harus jelas sehingga dapat dipikirkan, didalami, dan dipecahkan oleh siswa. Dari persoalan yang diajukan akan tampak jelas tujuan dari seluruh proses pembelajaran atau penyelidikan. Bila persoalan ditentukan oleh guru perlu diperhatikan bahwa persoalan itu real, dapat dikerjakan oleh siswa, dan sesuai dengan kemampuan siswa. Persoalan yang terlalu tinggi akan membuat siswa tidak semangat, sedang persoalan yang terlalu mudah yang sudah mereka ketahui tidak menarik minat siswa. Sangat baik bila persoalan itu sesuai dengan tingkat hidup dan keadaan siswa.

2. Membuat hipotesis.

Langkah berikutnya adalah siswa diminta untuk mengajukan jawaban sementara tentang suatu persoalan. Inilah yang disebut hipotesis. Hipotesis siswa perlu dikaji apakah jelas atau tidak. Bila belum jelas, sebaiknya guru mencoba membantu memperjelas maksudnya lebih dulu. Guru diharapkan tidak memperbaiki hipotesis siswa yang salah, tetapi cukup memperjelas maksudnya saja. Hipotesis yang salah nantinya akan kelihatan setelah pengambilan data dan analisis data yang diperoleh. 
3. Mengumpulkan data.

Langkah selanjutnya adalah siswa mencari dan mengumpulkan data sebanyakbanyaknya untuk membuktikan apakah hipotesis mereka benar atau tidak.

4. Menganalisis data.

Data yang sudah dikumpulkan harus dianalisis untuk dapat membuktikan hipotesis apakah benar atau tidak.

5. Ambil kesimpulan.

Dari data yang telah dikelompokkan dan dianalisis, kemudian diambil kesimpulan dengan generalisasi. Setelah diambil kesimpulan, kemudian dicocokkan dengan hipotesis asal, apakah hipotesis kita diterima atau tidak.

\section{Hasil Belajar}

Hasil belajar yang diuraikan oleh Hendrawan, (2014) yang menyatakan bahwa hasil belajar merupakan perubahan-perubahan pada diri siswa, baik yang menyangkut aspek kognitif, afektif, dan psikomotor sebagai hasil dari kegiatan belajar.Ranah kognitif berfokus pada perilaku yang menekankan aspek intelektual, seperti pengetahuan dan keterampilan berpikir.Ranah afektif mencakup perilaku yang terkait dengan dengan emosi, misalnya perasaan, nilai, minat, motivasi, dan sikap. Sedangkan ranah psikomotorik mencakup perilaku yang menekankan fungsi manipulatif dan keterampilan motorik/ kemampuan fisik, berenang dan mengoperasikan mesin.

Pendapat yang senada juga diungkapkan oleh Nawawi (dalam Ibrahim, 2017) yang menyatakan bahwa hasil belajar diartikan sebagai tingkat keberhasilan siswa dalam mempelajari materi pelajaran di sekolah yang dinyatakan dalam skor yang diperoleh dari hasil tes mengenal sejumlah materi pelajaran tertentu.

Berdasarkan uraian pendapat di atas, peneliti menyimpulkan bahwa hasil belajar adalah kemampuan-kemampuan (afektif, kognitif, dan psikomotorik) yang dicapai siswa setelah mengikuti pengalaman belajar (KBM) sehingga membawa perubahan dan pembentukan tingkah laku yang relatif menetap. Dalam penelitian ini lebih difokuskan pada hasil belajar aspek kognitif dan psikomotorik saja. Peneliti mereduksi aspek afektif dikarenakan penelitian ini berkaitan dengan kemampuan siswa dalam menguasai materi pelajaran. Selain itu, waktu yang diberikan untuk melaksanakan penelitian ini terbilang singkat. Oleh karena itu, apabila aspek afektif turut diukur, maka penelitian akan melebihi batas waktu yang diberikan dari pihak sekolah. Sehingga nantinya akan berdampak pada hasil penelitian yang didapat kurang optimal.

\section{Faktor yang mempengaruhi Hasil Belajar}

Faktor-faktor yang mempengaruhi hasil belajar dibedakan atas dua kategori, yaitu faktor internal dan faktor eksternal. Kedua faktor tersebut saling mempengaruhi dalam proses belajar individu sehingga menentukan kualitas hasil belajar (Baharuddin dan Wahyuni, 2017)

1) Faktor internal

Faktor internal adalah faktor-faktor yang berasal dari dalam diri individu dan dapat mempengaruhi hasil belajar individu. Faktorfaktor internal ini meliputi faktor fisiologis dan psikologis.

a. Faktor fisiologis

Faktor fisiologis adalah faktor-faktor yang berhubungan dengan kondisi fisik individu. Faktor ini dibedakan menjadi dua macam. Pertama, keadaan tonus jasmani. Keadaan tonus jasmani pada umumnya sangat mempengaruhi aktivitas belajar seseorang. Kedua, keadaan fungsi jasmani atau fisiologis. Selama proses belajar berlangsung, peran fungsi fisiologi pada tubuh manusia sangat mempengaruhi hasil belajar terutama panca indera.

b. Faktor psikologis

Faktor psikologis, adalah keadaan psikologis seseorang yang dapat mempengaruhi proses belajar. Beberapa faktor psikologis yang utama mempengaruhi proses belajar yaitu kecerdasan siswa, motivasi, minat, sikap, dan bakat.

2) Faktor eksogen atau eksternal

Faktor eksternal juga dapat mempengaruhi hasil belajar siswa. Menurut Syah sebagaimana dikutip dalam Baharuddin dan Wahyuni (2017), faktor-faktor eksternal yang mempengaruhi hasil belajar dapat digolongkan menjadi dua golongan, yaitu faktor lingkungan sosial dan faktor lingkungan non sosial.

a. Lingkungan sosial

Lingkungan sosial terdiri dari lingkungan sosial sekolah, lingkungan sosial masyarakat dan lingkungan sosial keluarga.

b. Lingkungan non sosial

Faktor-faktor yang termasuk dalam lingkungan nonsosial adalah: pertama, lingkungan alamiah, seperti kondisi udara yang segar, tidak panas dan tidak dingin, sinar yang 
tidak terlalu silau atau kuat, suasana yang sejuk dan tenang. Kedua, factor instrumenal, yaitu perangkat belajar yang dapat digolongkan dua macam. Pertama, hardware, seperti gedung sekolah, alat-alat belajar, fasilitas belajar, lapangan olahraga dan sebagainya. Kedua, software, seperti kurikulum sekolah, peraturan sekolah dan buku.

\section{Penelitian yang Relevan Terkait Model Inquiry Terhadap Hasil Belajar}

Penelitian yang relevan dari beberapa penelitian terdahulu yang diambil dari jurnal untuk dijadikan bahan referensi komparasi serta perbandingan keaslian penelitian. Selain itu bisa dijadikan sebagai penyempurnaan penelitian:

Penelitian yang dilakukan Sri Rahayu, (2011) dengan judul Pengaruh Penggunaan Model Pembelajaran Inkuiri Terhadap Hasil Belajar IPA. Hasil penelitian ini menunjukkan bahwa diperoleh skor thitung $>\mathrm{t}$-tabel $(2,1667>2,0227)$. Nilai ratarata siswa yang di-beri perlakuan dengan model inkuiri yaitu 75,111 sedangkan siswa yang diberi perla-kuan model langsung yaitu 68. Jadi dapat disimpulkan bahwa model pembelajaran in-kuiri lebih baik daripada model pembelajaran langsung terhadap hasil belajar IPA materi sifat-sifat cahaya pada siswa kelas V se-Gugus Hasanudin Kecamatan Cepogo tahun 2012/2013. Dengan demikian H0 ditolak. Hal ini berarti terdapat perbedaan pengaruh antara model inkuiri dan model langsung terhadap hasil belajar IPA. Hasil belajar IPA dengan perlakuan model Inkuiri lebih baik dari pada model langsung.

Penelitian suadara Purwaningsih, (2016) dengan judul Studi Komparatif Pengaruh Model Pembelajaran Inquiry Terbimbing Dan Problem Based Learning (PBL) Hasil Belajar Pada Mata Pelajaran TIK Siswa Kelas X di SMA Laboratorium Undiksha Singaraja Tahun Ajaran 2015/2016. Hasil penelitian ini adalah adanya perbedaan yang signifikan dalam penerapan model pembelajaran Inquiry Terbimbing dan Problem Based Learning terhadap hasil belajar siswa kelas X SMA Laboratorium Undiksha Singaraja Tahun Ajaran 2015/2016. Hal tersebut dapat dilihat pada pengujian hipotesis dengan menggunakan rumus anava satu jalur, kriteria pengujian adalah apabila nilai Fhitung $36.10041>$ Ftabel 3.11 maka H0 ditolak dan Ha diterima dengan derajat kebebasan adalah $5 \%$ atau 0,05 . Sehingga perbedaan antar ketiga kelas signifikan. Jadi terdapat perbedaan hasil belajar TIK antara kelompok siswa yang mengikuti model pembelajaran Inquiry Terbimbing dan kelompok siswa yang mengikuti model pembelajaran Problem Based Learning. Hasil kedua adalah model pembelajaran Inquiry Terbimbing lebih baik dari pada siswa yang mengikuti model pembelajaran Problem Based Learning. Hal tersebut dapat dilihat dari skor ratarata model pembelajaran inquiry adalah 40.4333 dan model pembelajaran Problem Based Learning adalah 35.7241.

Penelitian yang dilakukan Yanti Bua (2015) yang berjudul Pengaruh penerapan model pembelajaran Inkuiri Terbimbing(Guided Inquiri)terhadap hasil belajar siswa di Sekolah Dasar. Hasil Penelitian ini bertujuan untuk mengetahui pengaruh pembelajaran inkuiri terbimbing terhadap hasil belajar siswa. Rancangan penelitian ini Quasi-Experimental dengan menggunakan One Group Pre-test and Post-test Design yang diterapakan pada siswa kelas IV-B SDN Lidah Wetan II/462 Surabaya. Teknik pengumpulan data yang digunakan berupa tes hasil belajar dan angket. Teknik analisis data yang digunakan adalah uji normalitas dan uji hipotesis. Hasil uji normalitas adalah pretest $=0,310$ dan $r_{11}$ posttest $=0,444$. Pada uji t diperoleh hasil bahwa $t_{\text {hitung }}$ adalah 9,25 dan $t_{\text {tabel }}$ adalah 2,02. Hal Sedangkan, hasil angket berada di kategori sangat baik yaitu 91,21\%. Berdasarkan data hasil penelitian tersebut, dapat disimpulkan bahwa pembelajaran inkuiri terbimbing berpengaruh terhadap hasil belajar siswa kelas IV SDN Lidah Wetan II/462 Surabaya.

Penelitian yang dilakukan Hafiza Fahmia (2019) yang berjudul Pengaruh Model Guided Inquiry terhadap Hasil Belajar Siswa pada Pembelajaran Matematika Siswa SD Kota Bengkulu.

Penelitian ini bertujuan untuk mengetahui pengaruh model inkuiri terbimbing terhadap hasil belajar siswa pada pembelajaran Matematika di kelas V SD Gugus XII Kota Bengkulu. Jenis penelitian ini adalah penelitian eksperimental semu dengan desain studi yang hanya cocok dengan desain kelompok kontrol pretest-posttest. Populasi dalam penelitian ini adalah semua siswa kelas V SD kelompok XII yang terdiri dari 5 sekolah dasar. Berdasarkan hasil uji homogenitas, sampel dalam penelitian ini adalah siswa kelas V SDN 99 sebagai kelas eksperimen dan siswa kelas V SDN 81 sebagai kelas kontrol. Instrumen penelitian yang digunakan adalah soal tes objektif yang terdiri dari 20 item. Analisis data yang digunakan adalah analisis 
deskriptif, uji prasyarat dan analisis inferensial yaitu uji-t. Berdasarkan analisis data hasil penelitian, diperoleh nilai rata-rata hasil posttest kelas eksperimen menggunakan model inkuiri terbimbing yaitu 78.120 dan kelas kontrol menggunakan pembelajaran konvensional yaitu 62.789. T-test kedua kelas sampel dengan tingkat signifikansi? = 0,05 , diperoleh hitung $=4,730$ sedangkan ttabel $=$ 2.000, t hitung $>$ ttabel sehingga HO ditolak dan $\mathrm{Ha}$ diterima. Peningkatan persentase hasil belajar di kelas eksperimen lebih tinggi dari kelas kontrol yaitu $83,36 \%$ di kelas eksperimen dan kelas kontrol $33,98 \%$. Dengan demikian dapat disimpulkan ada pengaruh yang signifikan hasil belajar siswa yang mengikuti pembelajaran menggunakan model inkuiri terbimbing.

Penelitian yang dilakukan Ni Wayan Juniati (2017) yang berjudul Penerapan Model Pembelajaran Inkuiri Untuk Meningkatkan Hasil Belajar IPA. Hasil Penelitian ini bertujuan untuk mengetahui hasil belajar IPA pada penerapan model pembelajaran Inkuiri pada siswa kelas IV SD No.5 Gulingan tahun pelajaran 2016/2017. Jenis penelitian ini adalah penelitian tindakan kelas yang dilaksanakan dalam dua siklus. Setiap siklus terdiri atas tahap perencanaan, pelaksanaan tindakan, observasi/evaluasi, dan refleksi. Subjek penelitian ini adalah siswa kelas IV di SD No. 5 Gulingan, sebanyak 20 orang siswa. Data yang dikumpulkan dianalisis dengan menggunakan metode tes. Data yang didapatkan dari metode tes selanjutnya dianalisis dengan teknik deskriptif kuantitatif. Hasil penelitian ini menunjukan bahwa pembelajaran IPA dengan menggunakan model pembelajaran Inkuiri dapat meningkatkan hasil belajar siswa kelas IV di SD No. 5 Gulingan tahun pelajaran 2016/2017. Pada siklus I rata-rata hasil belajar IPA siswa sebesar $72,75 \%$ pada kategori sedang dan meningkat menjadi $80 \%$ pada siklus II yang berada pada kategori tinggi. Terjadi peningkatan sebesar $7,25 \%$. Jadi model pembelajaran Inkuiri dapat meningkatkan hasil belajar IPA siswa kelas IV di SD No. 5 Gulingan tahun pelajaran 2016/2017.

Penelitian yang dilakukan I Wayan Sudiana (2013) yang berjudul Pengaruh model pembelajaran Inkuiri terbimbing terhadap hasil belajar Matematika siswa Kelas III SD di Gugus I Kecamatan Buleleng. Hasil Penelitian ini bertujuan untuk mengetahui perbedaan hasil belajar matematika antara kelompok siswa yang dibelajarkan menggunakan model pembelajaran inkuiri terbimbing dengan kelompok siswa yang dibelajarkan dengan menggunakan model pembelajaran konvensional pada siswa kelas III semester 2 tahun pelajaran 2012/ 2013 di SD Gugus I Kecamatan Buleleng, Kabupaten Buleleng. Penelitian ini menggunakan rancangan "post test only control group design". Dari delapan sekolah yang ada di SD Gugus I Singaraja terpilih dua sekolah untuk sampel penelitian dengan teknik simple random sampling yaitu SD No. 5 Banyuning sebagai kelompok eksperimen dan SD No.6 Banyuning sebagai kelompok kontrol. Data penelitian ini diambil dengan menggunakan instrument berupa seperangkat tes obyektif. Metode yang digunakan dalam penelitian ini adalah metode analisis statistik deskriptif dan statistik iferensial. Berdasarkan hasil uji hipotesis yang dilakukan dengan teknik statistik uji-t ditemukan bahwa perbedaan hasil belajar matematika yang signifikan antara siswa yang dibelajarkan menggunakan model pembelajaran inkuiri terbimbing dengan siswa yang dibelajarkan menggunakan model pembelajaran konvensional. Dari hasil uji-t diperoleh $\mathrm{t}_{\text {hitung }}=4,87$ dan $\mathrm{t}_{\text {tabel }}=2,000$ hal ini berarti $\mathrm{t}_{\text {hitung }}>\mathrm{t}_{\text {tabel }}$ maka H0 ditolak dan H1 diterima. Rata-rata siswa yang menggunakan model pembelajaran inkuiri terbimbing adalah 23,37 kategori sangat baik sedangkan siswa yang menggunakan model pembelajaran konvensional adalah 17,51 kategori baik, ini berarti siswa yang mengikuti pembelajaran dengan menggunakan model pembelajaran inkuiri terbimbing lebih baik dari pada siswa yang mengikuti pembelajaran dengan menggunakan model pembelajaran konvensional.

\section{KESIMPULAN DAN SARAN}

\section{Kesimpulan}

Berdasarkan hasil penelitian dapat diambil kesimpulan bahwa terdapat pengaruh model pembelajaran Inquiry terhadap peningkatan hasil belajar siswa pada operasi hitung bilangan cacah di kelas VI SD Negeri Balerejo 1 dan SD Negeri BrakasTerdapat pengaruh model pembelajaran Inquiry terhadap peningkatan hasil belajar siswa pada materi operasi hitung bilangan cacah di kelas VI SD Negeri Balerejo 1, Berdasarkan ouput SPPS dapat dijelaskan bahwa pada pretest kelas Inquiri yaitu kelas VI di SD Negeri Balerejo 1 mendapat nilai minimum 33.00 sedangkan nilai maksimum 67.00 dan mean atau rata-rata 52.87, Standr deviasi 8.61. pada tes posttest kelas Inquiri memiliki ratarata/ mean sebesar 74, 93, standar deviasi 10,185, nilai minimum 57, dan nilai maksimal hal ini 
berdasarkan diperoleh nilai Sig. (2-tailed) diperoleh $0.000<0.05$, atau t-hitung $10.660>$ t-tabel 1.69236 maka dapat disimpulkan bahwa ada perbedaan ratarata pre-test kelas dengan post-test. Pengaruh yang diberikan sebesar 22,91. Berdasarkan nilai $\mathrm{N}$ Gain diketahui bahwa indeks gain peningkatan hasil belajar peserta didik kelas inquiry yang termasuk kategori tinggi sebanyak 7 peserta didik atau $21,21 \%$, yang termasuk kategori peningkatan hasil belajar sedang sebanyak 20 peserta didik atau $60,61 \%$, dan yang termasuk kategori mengalami peningkatan hasil belajar rendah sebanyak 6 peserta didik atau $18,18 \%$.

\section{Saran}

Beberapa saran terkait penelitian ini diantaranya adalah:

1. Berdasarkan hasil penelitian bahwa model pembelajaran Inqury lebih tepat digunakan dalam pembelajaran materi operasi hitung bilangan cacah di kelas VI SD Negeri. Oleh sebab itu diharapkan para guru mampu mengiplementasikan model pembelajaran Inqury lebih inovatif lagi.

2.Guru perlu menggunakan model pembelajaran yang tepat agar hasil belajar siswa lebih meningkat lagi.

3.Guru dan sekolah perlu terus mengembangkan model pembelajaran yang lebih inovatif agar siswa tidak bosan dan lebih maksimal dalam menerima maeri pelajaran sesuai dengan pendekatan dan model yang lebih menarik.

\section{DAFTAR PUSTAKA}

Rina Agustin. (2014). Inovasi Model Pembelajaran Inquiri. Jakarta: Kencana.

Baharudin dan wahyuni (2017). Faktor-faktor Hasil Belajar Bandung: Refika Aditama

Hafiza Fahmia (2019) yang berjudul Pengaruh Model Guided Inquiry terhadap Hasil Belajar Siswa pada Pembelajaran Matematika Siswa SD Kota Bengkulu. Jurnal Riset Pendidikan Dasar Volume 2 Nomor 3 Tahun 2019

Hendrawan (2014). Hasil Belajar dan Pembelajaran. Jakarta: Rineka Cipta.

I Wayan Sudiana (2013) yang berjudul Pengaruh model pembelajaran Inkuiri terbimbing terhadap hasil belajar Matematika siswa Kelas III SD di Gugus I Kecamatan Buleleng
Jurnal Mimbar PGSD UNDIKSHA Volume 1 Nomor 1 Tahun 2013

Kunandar. (2017). Model-Model Pembelajaran Inovatif. Bandung: Alfabeta.

Ni Wayan Juniati (2017) yang berjudul Penerapan Model Pembelajaran Inkuiri Untuk Meningkatkan Hasil Belajar IPA. Jurnal Ilmiah Sekolah Dasar Volume 1 Nomor 1 Tahun 2017

Paul Suparno. (2017) Metodologi Pembelajaran Fisika. Yogyakarta: Universitas Sanata Dharma.

Pranowo (2014). Teori Belajar dan Pembelajaran. Bogor: Ghalia Indonesia

Purwaningsih. (2016). Studi Komparatif Pengaruh Model Pembelajaran Inquiry Terbimbing Dan Problem Based Learning (PBL) Terhadap Motivasi dan Hasil Belajar Pada Mata Pelajaran TIK Siswa Kelas X di SMA Laboratorium Undiksha Singaraja Tahun Ajaran 2015/2016. Jurnal Pendidikan Volume 5, Nomor 2 tahun 2016. ISSN 22529063.

Purwanto. (2011). Evaluasi Hasil Belajar. Yogyakarta: Pustaka Belajar.

Sri Rahayu. 2011. Pengaruh Penggunaan Model Pembelajaran Inkuiri Terhadap Hasil Belajar IPA . PGSD FKIP Universitas Sebelas Maret, Jl. Slamet Riyadi No. 449, Surakarta $\quad 57126 . \quad$ e-mail: yayukrahayu538@yahoo.co.id

Sugiyono. (2012). Metode Penelitian Kuantitatif, Kualitatif, dan $R$ \& $D$ Cetakan Ke 17. Bandung: Alfabeta.

Susanto, A. (2013). Teori Belajar Pembelajaran di Sekolah Dasar. Jakarta: Prenadamedia Group.

Thobroni (2016). Hasil Belajar dan Faktor-Faktor yang Mempengaruhinya. Jakarta: Rineka Cipta.

Trianto. (2017). Model-Model Pembelajaran Inovatif Berorientasi Konstruktivistik. Jakarta: Prestasi Pustaka.

Wina Sanjaya. (2016). Strategi Pembelajaran. Jakarta: Kencana.

Yanti Bua (2015) yang berjudul Pengaruh penerapan model pembelajaran Inkuiri Terbimbing(Guided Inquiri)terhadap hasil belajar siswa di Sekolah. Jurnal penelitian Pendidikan Guru sekolah Dasar Vol 3 no 2 tahun 2015 